\title{
PENGARUH PEMBERIAN KOMPRES HANGAT TERHADAP NYERI PADA PASIEN FRAKTUR POST OPERASI DI RST. DR. REKSODIWIRYO PADANG TAHUN 2017
}

\author{
Revi Neini Ikbal ${ }^{1}$, Rahmat Hidayat ${ }^{2}$ \\ ${ }^{1,2}$ STIKes Alifah, Jl. Khatib Sulaiman No. 52 B, Padang, 25000, Indonesia \\ Email: revineini@gmail.com
}

\begin{abstract}
ABSTRAK
Penelitian ini bertujuan untuk Mengetahui pengaruh pemberian kompres hangat terhadap nyeri pada pasien post operasi fraktur di RST. Dr. Reksodiwiryo Padang Tahun 2017. Penelitian ini berjenis Quasy eksperiment dengan desain one group pre-test and post-test yang telah dilaksanakan di RST. Dr.Reksodiwiryo Padang pada bulan Februari - Oktober 2017. Populasi seluruh pasien fraktur post operasi. Teknik pengambilan sampel secara purposive sampling dengan jumlah sampel sebanyak 10 orang. Hasil penelitian didapatkan rata-rata skala nyeri sebelum pemberian kompres hangat adalah 3,60, rata-rata skala nyeri sesudah pemberian kompres hangat adalah 2,20 , perbedaan rata-rata nyeri sebelum dan sesudah pemberian kompres hangat adalah sebesar 1,400 dengan standar deviasi 0.177. Berdasarkan hasil uji statistik wilcoxon didapatkan nilai $\mathrm{p}=0,006$. Dapat disimpulkan bahwa dukungan terdapat pengaruh pemberian kompres hangat terhadap nyeri pada pasien post operasi fraktur di RST. Dr. Reksodiwiryo, Diharapkan bagi rumah sakit agar dapat membuat SOP tentang penatalaksanaan nyeri pada pasien frakturpost operasi.
\end{abstract}

Kata Kunci: Kompres hangat, Nyeri, Fraktur

\section{ABSTRACT}

This study aims to determine the effect of giving warm compresses on pain in postoperative fracture patients in RST. Dr. Reksodiwiryo Padang Year 2017. This research type was Quasy experiment with one group pre-test and post-test design that has been implemented in RST. Dr. Reksodiwiryo Padang in February - October 2017. Populations were all postoperative fracture patients. The sampling technique was purposive sampling with 10 samples. The result showed that the average of pain scale before the warm compress was 3.60, the mean of pain scale after warm compress was 2.20 , the mean difference of pain before and after the warm compress was 1,400 with the standard deviation of 0.177. Based on statistical test results obtained Wilcoxon $p$ value $=0.006$. It can be concluded that support has an effect of giving warm compresses on pain in postoperative fracture patients in RST. Dr. Reksodiwiryo, It was expected for the hospital to be able to make SOP about the management of pain in patient fracture post operation

Keywords: Warm compresses, Pain scale, Fracture 


\section{PENDAHULUAN}

Fraktur merupakan ancaman potensial maupun aktual terhadap integritas seseorang, sehingga akan mengalami gangguan fisiologis maupun psikologis yang dapat menimbulkan respon berupa nyeri. Nyeri tersebut adalah keadaan subjektif dimana seseorang memperlihatkan ketidaknyamanan secara verbal maupun non verbal. Padahal rasa nyaman merupakan salah satu kebutuhan dasar individu dan merupakan tujuan diberikannya asuhan keperawatan pada seseorang di rumah sakit (Kemenkes RI, 2014).

Menurut World Health Organization (WHO), kasus fraktur terjadi di duniakurang lebih 13 juta orang pada tahun 2012,dengan angka prevalensi sebesar $2,7 \%$.Sementara pada tahun 2013 terdapatkuranglebih 18 juta orang dengan angkaprevalensi sebesar 4,2\%. Tahun 2014 meningkat menjadi 21 juta orang denganangka prevalensi $3,5 \%$. Terjadinya frakturtersebut termasuk didalamnya insidenkecelakaan, cedera olahraga, bencanakebakaran, bencana alam dan lainsebagainya.

Survei kesehatan nasional mencatat bahwa kasus fraktur pada tahun 2012 menunjukan bahwa prevalensi fraktur secara nasional sekitar $27,7 \%$. Prevalensi ini khususnya pada laki-laki mengalami kenaikan dibanding tahun 2013 dari $51,2 \%$ menjadi $54,5 \%$. Sedangkan pada perempuan sedikit menurun yaitu sebanyak $2 \%$ di tahun 2014, pada tahun 2015 menjadi 1,2\% (Kemenkes RI, 2015). Berdasarkan data dari Dinas Kesehatan Provinsi Sumatera Barat tahun 2015 didapatkan sekitar 2.700 orang mengalami insiden fraktur, $56 \%$ diantaranya mengalami kecacatan fisik, 24\% mengalami kematian, $15 \%$ mengalami kesembuhan dan 5\% mengalami gangguan psikologis atau depresi (Dinkes Sumbar, 2015).

Fraktur yang terjadi dapatmenimbulkan gejala yang umum yaitunyeri atau rasa sakit, pembengkakan dankelainan bentuk tubuh. Nyeri merupakanperasaan yang tidak nyaman dan bersifatsubjektif dimana hanya penderita yangdapat merasakannya. Untuk itu perlumencari pendekatan yang paling efektifdalam upaya mengontrol nyeri(Smeltzer, 2009).

Kompres hangat adalah suatu metode alternatif non farmakologis untuk mengurangi nyeri. Pelaksanaannya dilakukan dengan menggunakan kantong diisi dengan air hangat dengan suhu tertentu kemudian menempatkan pada bagian yang nyeri. Pemberian kompres hangat ini dilakukan selama 30 menit, selanjutnya dilakukan pengukuran nyeri setelah 30 menit pengompresan dengan skala nyeri VAS (Visual Analog Scale). Penggunaan kompres hangat bertujuan untuk mengetahui pengaruh kompres hangat pada pasien fraktur ekstremitas tertutup (Asmadi, 2008). Menurut Smeltzer \& Bare (2005), prinsi kerja kompres hangat dengan menggunakan buli-buli hangat yang dibungkus kain yaitu secara konduksi dimana terjadi pemindahan hangat dari buli-buli kedalam tubuh sehingga akan menyebabkan pelepasan pembuluh darah dan akan terjadi penurunan ketegangan otot sehingga nyeri yang dirasakan akan berkurang atau hilang.

Berdasarkan survei awal yang dilakukan di ruangan bedah pada tanggal 26 Maret 2017 didapatkan jumlah pasien fraktur pada tahun 2015 adalah sebanyak 377 orang, sedangkan pada tahun 2016 meningkat menjadi 398 orang. Sementara pada tahun 2017 (Januari s/d Februari 2017) didapatkan jumlah pasien sebanyak 82 orang dengan rincian 45 orang fraktur ekstremitas atas dan 37 orang fraktur ekstremitas bawah.

Berdasarkan hasil wawancara pada tanggal 26 Maret 2017 dengan salah satu petugas yang ada di ruang rawat inap, didapatkan informasi bahwa penatalaksanaan nyeri pada pasien biasanya dengan pemberian obat yang mampu menghilangkan sensasi nyeri, sementara manajemen nyeri secara non farmakologi jarang dilakukan. Sedangkan hasil wawancara peneliti dengan 5 orang pasien post operasifraktur, didapatkan 3 orang diantaranya mengatakan nyeri berada pada skala sedang, 2 orang pada skala nyeri ringan.

\section{METODE PENELITIAN}

Jenis penelitian ini bersifat quasi eksperiment dengan desain one group pre-test and post-test. Penelitian ini telah dilaksanakan di RST. Reksodiwiryo Padang pada bulan Februari - September 2017. Populasi adalah seluruh pasien fraktur dan sampel sebanyak 10 orang diambil dengan purposive Sampling. Pengolahan data melalui analisa data secara univariat dan bivariat menggunakan uji wilcoxon dengan tingkat kepercayaan 95\% $=0,05$. 


\section{HASIL}

\section{A. Analisa Univariat}

\section{Karakteristik Responden}

Berdasarkan hasil penelitian didapatkan bahwa lebih dari separoh (60\%) responden berumur $\geq 30$ tahun, sebagian besar $(90 \%)$ responden berjenis kelamin laki-laki dan lebih dari separoh (60\%) responden berpendidikan SMP.

\section{Rerata Nyeri Pada Pasien Post Operasi Fraktur Sebelum Pemberian Kompres Hangat}

\section{Tabel 4.1}

Nyeri Pada Pasien Post Operasi Fraktur Sebelum Pemberian Kompres Hangat di RST. Dr. Reksodiwiryo Padang Tahun 2017

\begin{tabular}{cccccc}
\hline $\begin{array}{c}\text { Kelompo } \\
\mathbf{k}\end{array}$ & Mean & Median & SD & Min & Maks \\
\hline Pretest & 3.60 & 3.50 & 0.966 & 2 & 5 \\
\hline
\end{tabular}

Berdasarkan tabel 4.1 diatas dapat dilihat bahwa rata-rata skala nyeri sebelum pemberian kompres hangat adalah 3,60 dengan nilai median 3.50 , standar deviasi 0.966 , sedangkan skala nyeri minimal 2 dan maksimal 5.

\section{Rerata Nyeri Pada Pasien Post Operasi Fraktur Sesudah Pemberian Kompres Hangat}

Tabel 4.2

Nyeri Pada Pasien Post Operasi Fraktur Sesudah Pemberian Kompres Hangat di RST. Dr. Reksodiwiryo Padang Tahun 2017

\begin{tabular}{cccccc}
\hline Kelompok & Mean & Median & SD & Min & Maks \\
\hline Postest & 2.20 & 2.00 & 0.789 & 1 & 3 \\
\hline
\end{tabular}

Berdasarkan tabel 4.2 diatas dapat dilihat bahwa rata-rata skala nyeri sesudah pemberian kompres hangat adalah 2,20 dengan nilai median 2.00, standar deviasi 0.789 , sedangkan skala nyeri minimal 1 dan maksimal 3.

\section{B. Analisis Bivariat}

Perbedaan Nyeri Sebelum dan Sesudah Pemberian Kompres Hangat pada Pasien Post Operasi Fraktur di RST. Dr. Reksodiwiryo Padang Tahun 2017

Tabel 4.3

Perbedaan Nyeri Sebelum Dan Sesudah Pemberian Kompres Hangat Pada Pasien Post Operasi Fraktur di RST. Dr. Reksodiwiryo Padang Tahun 2017

\begin{tabular}{cccccc}
\hline Nyeri & $\mathrm{n}$ & Mean & $\begin{array}{c}\text { Standar } \\
\text { Deviasi }\end{array}$ & $\mathrm{Z}$ & Sig. \\
\hline Pre-Test & 10 & 3.60 & 0.966 & - & \\
Post-Test & 10 & 2.20 & 0.789 & 2.739 & 0,006 \\
Selisih & & 1.400 & 0.177 & & \\
\hline
\end{tabular}

Berdasarkan tabel 4.4 diatas dapat dilihat bahwa perbedaan rata-rata nyeri sebelum dan sesudah pemberian kompres hangat adalah sebesar 1,400 dengan standar deviasi 0.177. Berdasarkan hasil uji statistik wilcoxon didapatkan nilai $\mathrm{p}=0,006$. Karena $\mathrm{p}<0,05$ maka dapat disimpulkan bahwa Ho ditolak, artinya adanya pengaruh pemberian kompres hangat terhadap nyeri pada pasien post operasi fraktur di RST. Dr. Reksodiwiryo Padang Tahun 2017.

\section{Pembahasan}

\section{A. Analisi Univariat}

\section{Nyeri Pada Pasien Post Operasi Fraktur Sebelum Pemberian Kompres Hangat}

Berdasarkan hasil penelitian didapatkan bahwa rata-rata skala nyeri sebelum pemberian kompres hangat adalah 3,60 dengan nilai median 3.50 , standar deviasi 0.966 , sedangkan skala nyeri minimal 2 dan maksimal 5.

Nyeri merupakan masalah utama pada pasien pasca operasi sekaligus merupakan pengalaman multidimensi yang tidak menyenangkan akibat kerusakan jaringan. Mekanisme munculnya nyeri dimulai dengan adanya stimulus nyeri. Stimulus-stimulus tersebut dapat berupa biologis, zat kimia, hangat, listrik serta mekanik. Stimulus penghasil nyeri mengirimkan impuls melalui serabut saraf perifer, lalu memasuki medula 
spinalis dan menjalani salah satu dari beberapa rute saraf dan akhirnya sampai di dalam masa berwarna abu-abu di medula spinalis.

Hasil penelitian yang didapat peneliti didukung hasil penelitian Khodijah (2011), tentang efektifitas kompres hangat terhadap penurunan intensitas nyeri pasien fraktur di Rindu B RSUP H. Adam Malik Medan. Hasil penelitian didapatkan untuk kelompok intervensi yang diberi kompres hangat selama 10 menit, rata-rata nyeri sebelum kompres hangat 5,25 sedangkan untuk kelompok kontrol yang diberi kompres air biasa rata-rata nyeri sebelum kompres air biasa 4,74.

Menurut Asumsi peneliti, nyeri yang timbul pada pasien fraktur disebabkan karena adanya kerusakan jaringan tubuh yang disebabkan karena fraktur dan karena spasme otot sebagai salah satu respon tubuh adanya kerusakan jaringan tubuh. Selain itu juga, persepsi setiap individu dalam menanggapi nyeri itu berbeda-beda, tergantung bagaimana individu itu mengartikan nyeri, apakah sebagai sesuatu yang positif atau negatif serta banyak sekali faktor-faktor yang mempengaruhi persepsi seseorang terhadap nyeri misalnya usia, jenis kelamin, kebudayaan, makna nyeri, lokasi dan tingkat keparahan nyeri, perhatian terhadap nyeri, ansietas, keletihan, pengalaman nyeri sebelumnya, dukungan keluarga dan sosial.

\section{Nyeri Pada Pasien Post Operasi Fraktur Sesudah Pemberian Kompres Hangat}

Berdasarkan hasil penelitian didapatkan bahwa rata-rata skala nyeri sesudah pemberian kompres hangat adalah 2,20 dengan nilai median 2.00, standar deviasi 0.789 , sedangkan skala nyeri minimal 1 dan maksimal 3.

Secara garis besar ada dua manajemen untuk mengatasi nyeri yaitu manajemen farmakologi dan manajemen nonfarmakologi. Manajemen farmakologi merupakan manajemen kolaborasi antara dokter dengan perawat yang menekankan pada pemberian obat yang mampu menghilangkan sensasi nyeri, sedangkan manajemen nonfarmakologi merupakan manajemen untuk menghilangkan nyeri dengan menggunakan teknik manajemen nyeri meliputi, stimulus dan massage kutaneus, terapi es dan hangat (pemberian kompres dingin atau hangat), stimulus saraf elektris transkutan, distraksi, imajinasi terbimbing, hipnotis, dan teknik relasasi (Chandra, 2013).

Kompres hangat adalah suatu metode alternatif non farmakologis untuk mengurangi nyeri. Pelaksanaannya dilakukan dengan menggunakan kantong diisi dengan air hangat dengan suhu tertentu kemudian menempatkan pada bagian yang nyeri. Pemberian kompres hangat ini dilakukan selama 30 menit, selanjutnya dilakukan pengukuran nyeri setelah 30 menit pengompresan dengan skala nyeri VAS (Visual Analog Scale). Penggunaan kompres hangat bertujuan untuk mengetahui pengaruh kompres hangat pada pasien fraktur ekstremitas tertutup (Asmadi, 2008).

Hasil penelitian ini menunjukkan bahwa adanya penurunan tingkat nyeri pada pasien fraktur sesudah diberikan kompres hangat yang menjadi tingkat nyeri ringan. Hasil penelitian ini sejalan dengan teori bahwa kompres hangat merupakan metode memberikan rasa hangat pada klien dengan menggunakan cairan atua alat yang menimbulkan hangat pada bagian tubuh yang memerlukan. Efek hangat dari kompres dapat menyebabkan vasodilatasi pada pembuluh darah yang nantinya akan meningkatkan aliran darah ke jaringan. Dengan cara ini penyaluran zat asam dan makanan ke sel-sel diperbesar dan pembuangan dari zat-zat diperbaiki yang dapat mengurangi rasa nyeri yang disebabkan suplai darah ke endrometrium kurang.

\section{B. Analisis Bivariat}

\section{Perbedaan Nyeri Sebelum dan Sesudah Pemberian Kompres Hangat pada Pasien Post Operasi Fraktur}

Berdasarkan hasil penelitian didapatkan bahwa perbedaan rata-rata nyeri sebelum dan sesudah pemberian kompres hangat adalah sebesar 1,400 dengan standar deviasi 0.177. Berdasarkan hasil uji statistik wilcoxon didapatkan nilai $\mathrm{p}=0,006$. Karena $\mathrm{p}<0,05$ maka dapat disimpulkan bahwa Ho ditolak, artinya adanya pengaruh pemberian kompres hangat terhadap nyeri pada pasien post operasi fraktur di RST. Dr. Reksodiwiryo Padang Tahun 2017.

Menurut Indrawan, dkk (2013), dikatakan bahwa ada salah satu cara yang dapat diterapkan untuk mengurangi nyeri adalah pemberian kompres hangat untuk mengurangi nyeri ini sesuai dengan penelitian Indrawan, dkk (2013) 
dengan judul efektifitas pemberian kompres hangat terhadap penurunan nyeri. Hasil dari penelitian tersebut adalah bahwa setelah dilakukan kompres hangat selama 30 menit pada pasien, maka didapatkan bahwa hasil nyeri pasien menurun atau berkurang.

Hasil penelitian yang didapat peneliti didukung hasil penelitian Siti Khodijah (2011), tentang efektifitas kompres hangat terhadap penurunan intensitas nyeri pasien fraktur di Rindu B RSUP H. Adam Malik Medan. Hasil penelitian didapatkan untuk kelompok intervensi yang diberi kompres hangat selama 10 menit rata-rata nyeri setelah dilakukan intervensi ratarata nyeri menjadi 2,13, sedangkan untuk kelompok kontrol yang diberi kompres air biasa rata-rata nyeri dan setelah diberi kompres air biasa 4,38. Berdasarkan hasil analisa data diketahui bahwa intensitas nyeri pasien fraktur di Rindu B RSUP. H Adam Malik Medan yang diberikan kompres hangat mengalami penurunan nyeri yang signifikan, nilai $\mathrm{p}=0,000(\mathrm{p}<0,05)$, sedangkan pada kelompok kontrol yang diberi kompres air biasa tidak mengalami penurunan yang signifikan pvalue $=0,080$ dan hasil analisa data menunjukkan terdapat perbedaan yang signifikan antara kelompok intervensi dan kelompok kontrol setelah diberi kompres hangat dengan nilai pvalue $=0,000$.

Dari hasil penelitian, teori-teori yang ada dan hasil penelitian lainnya menurut analisis peneliti kompres hangat dapat menurunkan respon nyeri dikarenakan kompres hangat dapat menurunkan salah satu zat neurotransmiter yaitu prostaglandin yang memperkuat sensitivitas reseptor nyeri dengan cara menurunkan inflamasi (disebabkan spasme otot), karena kompres hangat menyebabkan vasokontriksi (penyempitan pembuluh darah) sehingga inflamsi menurun. Menurunnya inflamasi maka prostaglandin akan menurun pula produksinya, sehingga nyeri yang disebabkan spasme ptot dan kerusakan jaringan berkurang. Oleh karenanya perlu dilakukan intervensi mandiri ini dalam mengurangi respon nyeri khususnya pada pasien fraktur ekstremitas tertutup. Setelah membandingkan penelitian ini dengan penelitian sejenis dan dengan landasan teori yang ada, maka penelitian menarik kesimpulan bahwa ada pengaruh pemberian kompres hangat terhadap penurunan respon nyeri pada pasien fraktur ekstremitas tertutup.

Menurut analisa peneliti bahwa terdapat penurunan skala nyeri pada pasien fraktur setelah pemberian kompres hangat selama 3 hari berturut-turut. Adanya penurunan skala nyeri dari hari 1 sampai hari ke 3 namun pada hari kedua ada peningkatan nyeri disebabakan karena karena faktor lingkungan, faktor usia dan ansietassehingga mempengaruhi tingkat emosi klien dan akhirnya mempengaruhi skala nyeri.

\section{KESIMPULAN}

Rentang nyeri responden sebelum diberikan kompres hangat adalah minimal 3 dan maksimal 5 dan setelah diberikan kompres hangat menjadi minimal 1 maksimal 3. Terdapat pengaruh pemberian kompres hangat terhadap nyeri pada pasien post operasi fraktur di RST. Dr. Reksodiwiryo Padang Tahun 2017.

\section{DAFTAR PUSTAKA}

Arikunto, 2010. Prosedur Penelitian Suatu Pendekatan Praktik. Jakarta ; Rineka Cipta.

Bruner, 2014. Kapita Selekta Kedokteran. Edisi 4. Jakarta:Media. Aeskulapius

Chandra, 2013. Manajemen Penatalaksanaan Nyeri. Jakarta : Dian Rakyat.

Dinkes Sumbar, 2015.Profil Kesehatan Propinsi Sumatera Barat. Padang : Dinkes

Elia Purnamasari, 2014. Efektifitas kompres hangat terhadap penurunan intensitas nyeri pada pasien fraktur di RSUD Ungaran. Jurnal Penelitian.

Indrawan, dkk, 2013. Efektifitas pemberian kompres hangat terhadap penurunan nyeri.

Judha, 2012. Teori Pengukuran Nyeri \& Nyeri. Persalinan, Yogyakarta : Nuha Medika

Kemenkes RI, 2014. Profil Kesehatan Indonesia. Jakarta : Kemenkes

Mansjoer, 2013.Kapita Selekta Kedokteran, Edisi ke-3, Medica Aesculpalus, FKUI. Jakarta

Mellyanda Wurangia, dkk, 2014. Pengaruh kompres hangat terhadap penurunan skala nyeri pada penderita Gout Arthitis di Wilayah Kerja Puskesmas Bahu Manado. Jurnal Penelitian

NANDA, 2015. alih bahasa Made Sumarwati dan Nike Budhi Subekti. 2012. NANDA International Diagnosis Keperawatan Definisi dan Klasifikasi 2012-2014. Jakarta : EGC

Mubarak dan Chayatin, 2014. Buku Ajar Kebutuhan Dasar Manusia Teori Dan Aplikasi Dalam Praktik.Penerbit Buku Kedokteran EGC:Jakarta

Notoatmodjo, 2010. Metodologi Penelitian Kesehatan. Jakarta : Rineka Cipta. 
Oswari, 2014. Bedah dan Perawatannya, Jakarta PT Gramedia

Pinzon, 2014.Nyeri Fraktur. Jakarta : EGC.

Potter \& Perry, 2006. Buku Ajar Fundamental Keperawatan: Konsep,Proses dan Praktik.Edisi 4.EGC:Jakarta

Price, 2014. Patofisiologi Konsep Klinis ProsesProses Penyakit. Jakarta : EGC

Rizaldi, 2014. Bukupintar NyeriTulang dan Otot, Jakarta : Erlangga.

Sabudi N, 2013. Frozen Shoulder (Bahu Beku); Diakses tanggal 4/5/2017, dari http://www.indonesia media.com/index1003.htm

Sugiyono, 2010. Metode Penelitian Kuantitatif Kualitatif \& RND. Bandung : Alfabeta

Smeltzer \& Bare, 2012. Buku Ajar Keperawatan Medikal Bedah Brunner \& Suddarth. Edisi 8 Volume 2. Alih Bahasa H. Y. Kuncara, Monica Ester, Yasmin Asih, Jakarta : EGC

Tamsuri, 2013. Konsep Dan penatalaksanaan nyeri . Jakarta : EGC.

Uliyah \& Hidayat, 2013. Buku Ajar Kebutuhan Dasar Manusia ( KDM ), Pendekatan Kurikulum Berbasis Kompetensi. Surabaya : Health Books Publishing 